La Lepro 44, 4 (1975)

\title{
Effect of Antibiotics on the Capsular Structure of M. Lepraemurium
}

\author{
TSUNEHIKO HIRATA
}

(National Institute for Leprosy Research)

The effect of INH and DDS on the capsular structure of $M$. lepraemurium was studied at the light and the electron microscopical level.

Both drags did not have an effect on the capsular structure.

However, the bacilli were proved to be susceptible to INH and not to DDS. The cytoplasm of $M$. lepraemurium adminstrated INH was collapsed and Vacuolated.

\section{宿主内における鼠らい菌とその周辺構造 特に薬剤投与後における鼠らい菌の 周辺構造について}

\author{
平田恒彦 \\ (国立多摩研究所細菌研究室 $)$
}

（受付 1975年 7 月 24 日）

緒 言

さきに著者は, 宿主内における鼠らい菌の周辺構造に ついて研究し，それが三層構造になっていること，およ びその形成機序が菌の増殖過程と密接不可分な関係にあ り，菌体細胞壁に由来するものと菌体細胞質に由来する

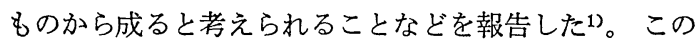
ような起源からも推察されるように, 三層構造の周辺物 質は非常に繊細な性質をもっており，いろいろな要因に よってその様相が変化するものと思われるが，まだはっ きりしたことは何も知られていない。

著者は鼠らい菌体周辺構造のもつ生物学的意義をさら に詳しく追求するために，上述の報告にひきつづき，こ の構造が治らい剤投与によってどのように影響されるか を検討することとした。

\section{方法および材料}

マウスに鼠らい腫が形成された段階で，換言すれば, 宿主細胞内鼠らい菌の周辺構造が完成した時点で, イン ニコチン酸ヒドラジッド（以下 INH）または $4: 4^{\prime}$-ジ アミノジフェニールスルフォン（以下 DDS）を連続的 に投与し，それによって周辺構造が示す変動のありさま を, 多数の菌について光顕と電顕を併用して観察するこ ととした。

即ち, 生後 $3 \sim 5$ 週の dd 系雌マウス (平均体重 約 $16.5 \mathrm{~g}$ ) の腹腔内に，鼠らい菌（ハワイ株）を約 $10^{6}$ 個接 種し，3カ月経過して鼠らい腫が生じた時期に，これら マウスを 1 群に 10 匹あて, 無処置の対照群, INH 投与 群，DDS 投与群の 3 群に分け，INH，DDS をそれぞ

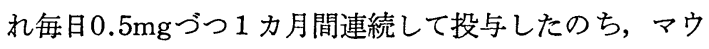


スを解剖し，肝，脾，リンパ腺の鼠らい腫を採取して材 料とした。

光顕ならびに電顕による検索法は,ささきに1詳細に報 告したとおりである。

\section{成 績}

1. 対照としての無処置群

光䫓的，電顕的いずれの所見も，前報1で述べた感染 成立過程と同様であった（Fig. 1)。

2. INH 投与群

光顕的染色所見では，いずれの臟器においても，無処 置群との差はみられなかった (Fig. 2)。

電顕的観察の結果では, いずれの臟器内の菌体も, 細 胞質に若干の損傷，つまり空胞化，線維化あるいは泡状 化をきたしていた。とくに，脾内の菌体では，醳素など により消化処理されたような像を示していた。しかし， 周辺のいわゆる層構造は鮮明に観察された（Fig. 5)。

また, 菌体の近くに, 細網様構造がところどころに観 察された (Fig. 5-2)。

3. DDS 投与群

光顕的染色所見は，臟器によって差がなかった (Fig. $3)$ 。

電顕的観察の結果においても，INH 投与群に比べ て，いずれの藏器内の菌体も，損傷はほとんど認められ なかった (Fig. 6)。

周辺の層構造には異常がなかったが，細網様構造は若 干みられた（Fig. 6)。

\section{考察}

化学療法剤の微生物細胞に対する形態学的並びに機能 的影響についての系能的な研究はまだ充分におこなわれ ていない2)。また，in vivo における薬剤の作用は，宿 主側の細胞とのつながりにおいて, 病原菌への作用機構 を詳細にわたって検討することは容易でなく，まだ不明 の点が多い。

従って，投与された INH または DDS がどのよう にして直接的または間接的に宿主細胞内鼠らい菌に影響 を与えるかという問題の解析は全く抜きにして，ただ， INH または DDS 投与の結果としての鼠らい菌形態の
変化について記載し得るだけである。

前述したように, INH 投与群では菌体細胞質の変 化がみられたが，この細胞質の変性はやがて菌の顆粒化 へとつながっていくものであり，鼠らいに INH が効 くという現象のよって来るところのものであろう3。 INH 投与によるこの 鼠らい菌細胞質の変性は, 一般の 細胞において細胞組織化学的方法による酵素処理などの 際にみられる細胞質変化の状態と非常に類似する所見で あり,この点から考察すると, 鼠らい菌細胞質の INH による変化は細胞質蛋白を主体におこったものであろ う。しかし，それにもかかわらず，菌体周辺の層構造は $\mathrm{INH}$ 投与の影響を受けておらず，これは周辺構造の物 質的特徴をはっきり示す現象ということができよう。

DDS 投与では，菌体細胞質および周辺構造の両者に おいて変化がみられなかった点は, DDS が単独では鼠 らいには効果がないといらことに一致している。

\section{結論}

鼠らい菌の周辺層構造が，INH や DDS などの薬凧 によって，どのような影響を受けるかを光顕的並びに電 顕的に検討した結果，INH 投与では，菌体の細胞質に 損傷をもたらすが，周辺層構造に対する影響はみられな かった。

DDS 投与では, 菌体の細胞質および周辺構造のいず れに対しても効果的な作用がみられなかった。

この論文を終わるにあたり，終始ご㭛篤なご指導を戴 き，また，ご校閲の労を賜った東京大学岩田和夫教授お よび国立多摩研究所中山哲第一研究部長に深甚の謝意を 表します。

\section{文献}

1）平田恒彦：宿主内に打ける鼠らい菌とその周辺 構造, 特に電顕像からみた 発生学的理論構築, レプラに投稿中.

2）シンポジウム，II．微生物細胞の表層構造をめ ぐって, 第26回 日本細菌学会関東支部総会（東 京), 日本細菌学雑誌，27，3，480-485（1972）。

3) 谷村忠保編: 鼠攋, 大阪大学医学部皮㲊科教室 （皮膚病研究所）発行（1953）。 


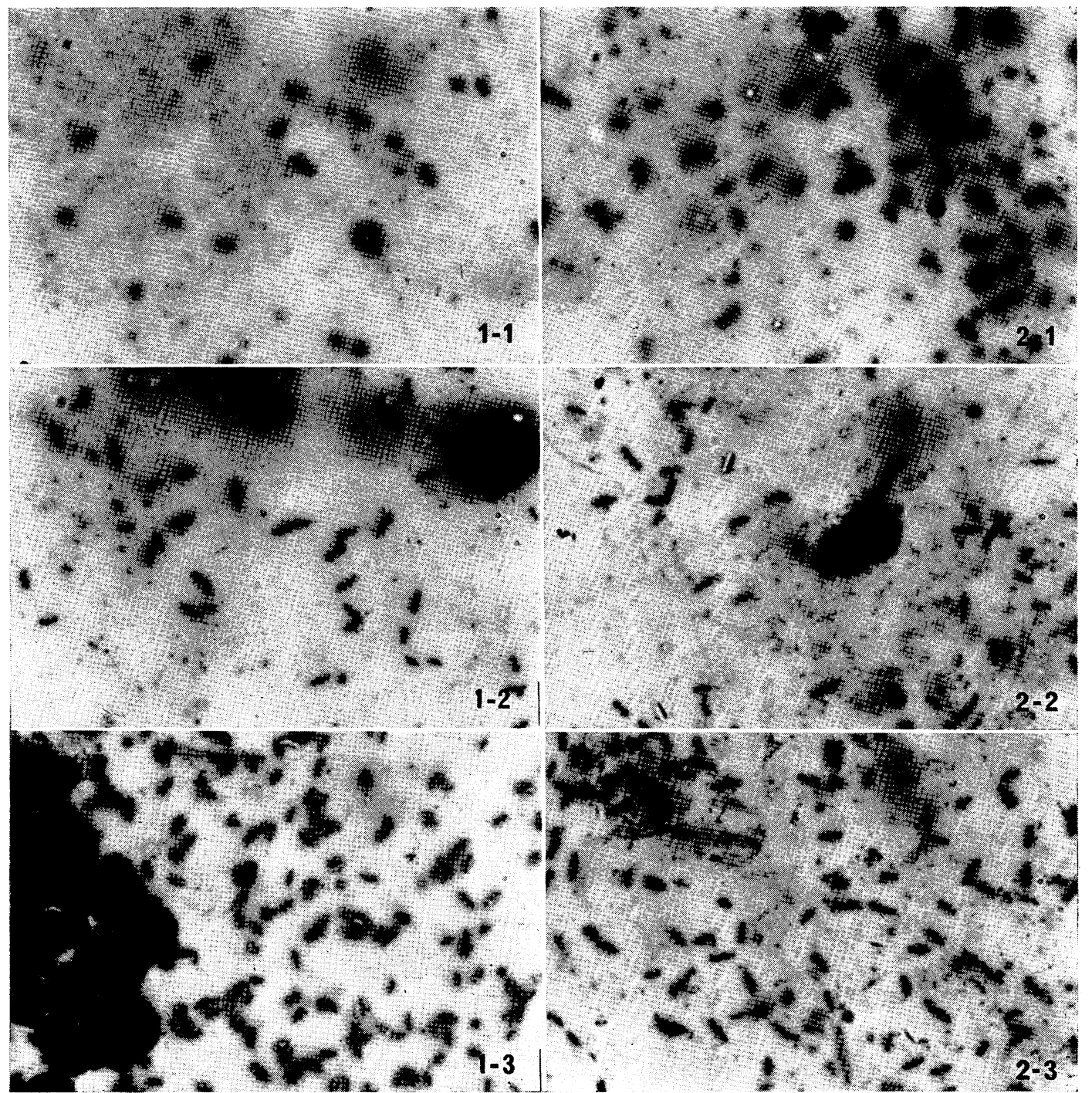

Fig. 1-1 無処置群マウス肝における鼠らい菌 の光顕染色像（周辺構造検索のため の染色方法1)による)

Fig. 1-2 無処置群マウス脾における鼠らい菌 の光顕染色像（周辺構造検索のため の染色方法1)による）

Fig. 1-3 無処置群マウスリンパ腺における鼠 らい菌の光顕染色像（周辺構造検索 のための染色方法1による)
Fig. 2-1 INH 投与群 マウス肝における鼠ら 以菌の光顕染色像（周辺構造検索の ための染色方法1)による)

Fig. 2-2 INH 投与群マウス脾における鼠ら 、菌の光顕染色像（周辺構造検索の ための染色方法1)による)

Fig. 2-3 INH 投与群 マウスリンパ腺におけ る鼠らい菌の光顕染色像 (周辺構造 検索のための染色方法1による) 


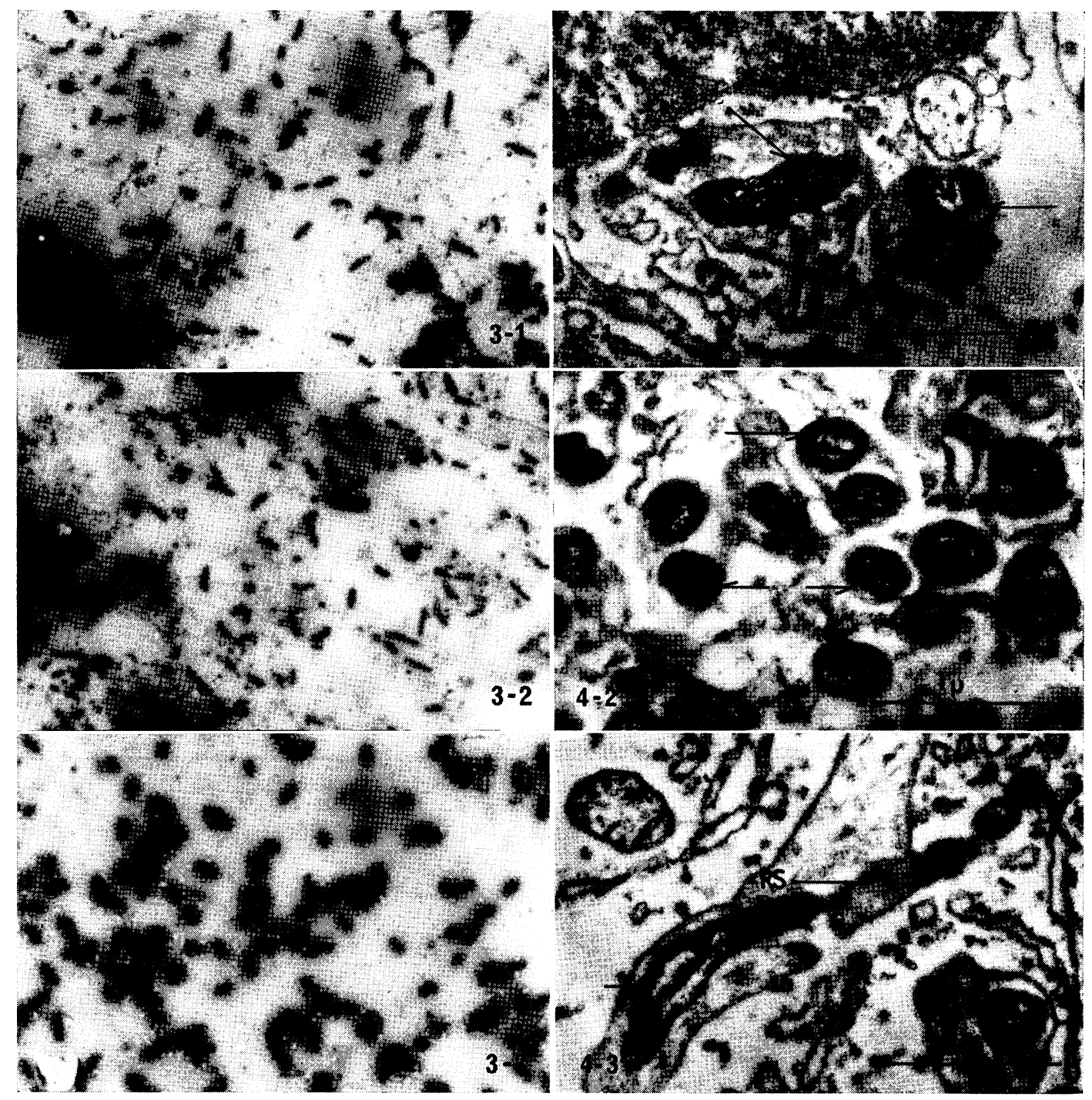

Fig. 3-1 DDS 投与群マウス肝における鼠ら い菌の光顕染色像 (周辺構造検荣の ための染色方法1による)

Fig. 3-2 DDS 投与群マウス脾における鼠ら い菌の光顕染色像 (周辺構造検索の ための染色方法1による)

Fig. 3-3 DDS 投与群マウスリンパ腺に㧍け る鼠らい菌の光顕染色像 (周辺構造 検索のための染色方法1による)
Fig. 4-1 無処置群マウス肝の鼠らい菌の電顕 像（矢印は層構造を示す）

Fig. 4-2 無処置群マウス脾の鼠らい菌の電顕 像（矢印は層構造を示す）

Fig. 4-3 無処置群マウスリンパ腺の鼠らい菌 の電顕像（記 号, RS : Reticular structure, 矢印は層構造を示す） 


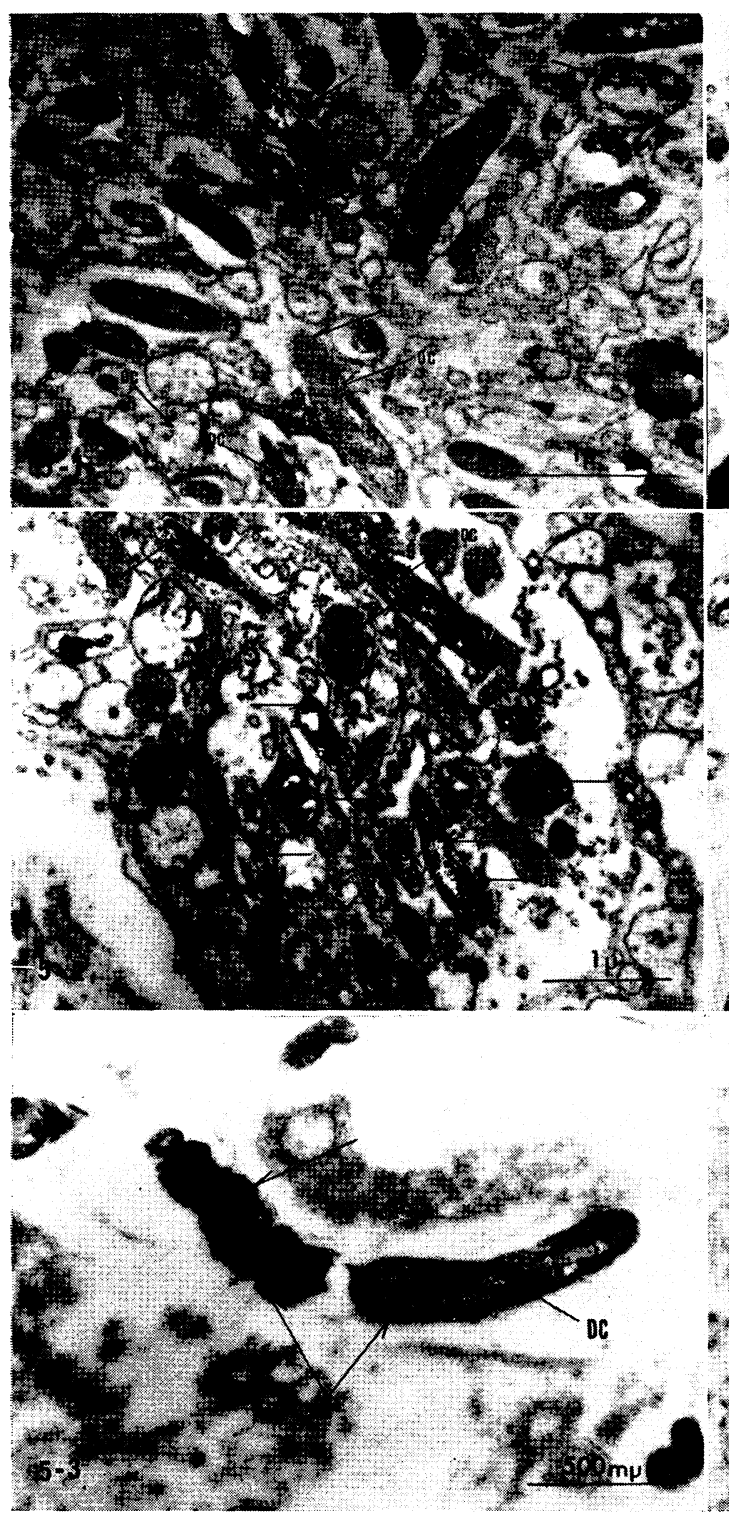

Fig. 5-1 INH 投与群マウス肝の鼠らい菌 の電顕像（記号, DC：Damaged cytoplasm，矢印は層構造を示す）

Fig. 5-2 INH 投与群マウス脾の鼠らい菌 の電顕像（記号, DC：Damaged cytoplasm, RS: Reticular structure，矢印は層構造を示す）

Fig. 5-3 INH 投与群マウスリンパ腺の鼠 らい菌の電顕像（記号, DC：Damaged cytoplasm, 矢印は層構造を 示す)
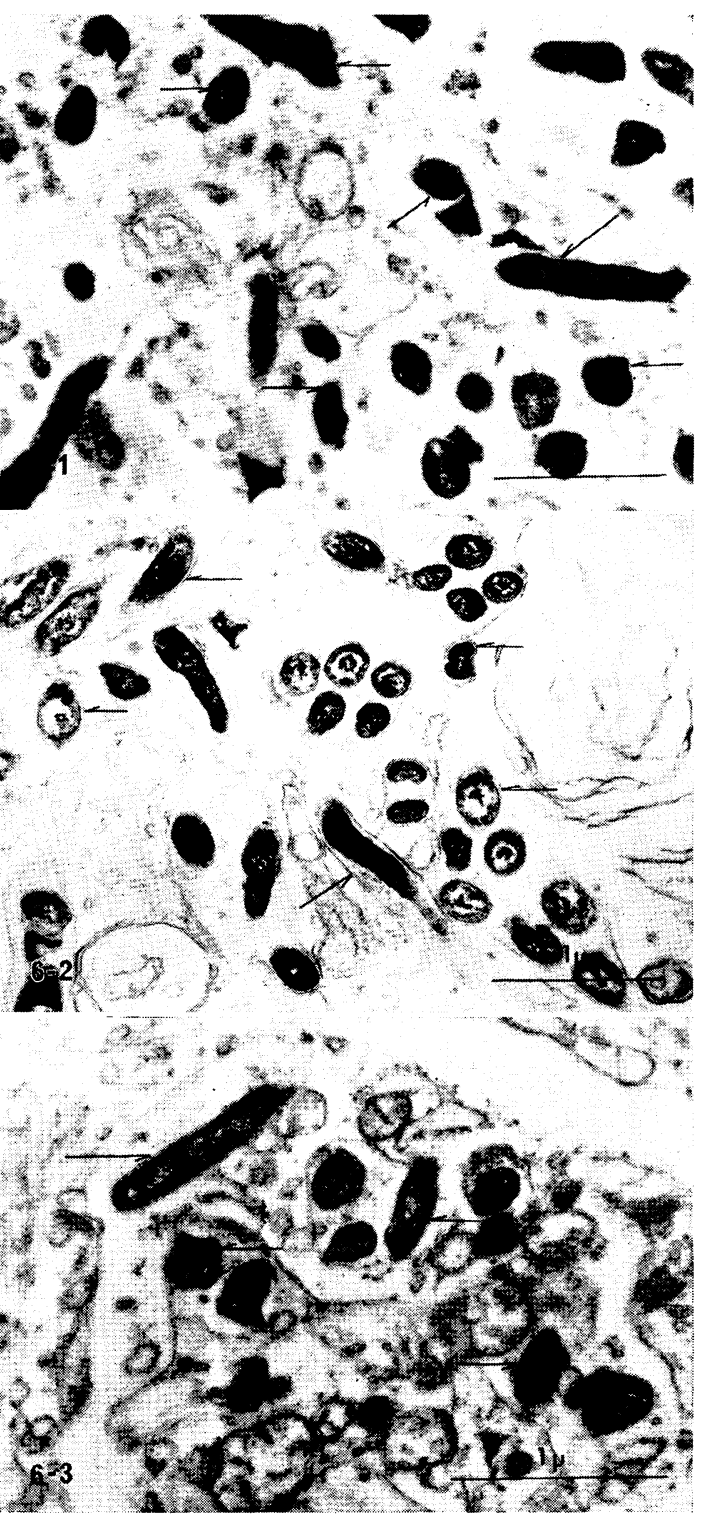

Fig. 6-1 DDS 投与群マウス肝の鼠らい菌の 電顕像（矢印は層構造を示す）

Fig. 6-2 DDS 投与群マウス脾の鼠らい菌の 電顕像（矢印は層構造を示す）

Fig. 6-3 DDS 投与群マウスリンパ腺の鼠ら い菌の電顕像 (矢印は層構造を示す) 